\title{
MECHANICAL HARVESTING OF PLUMS FOR PROCESSING WITH A CONTINUOUSLY MOVING COMBINE HARVESTER
}

\author{
Augustyn Mika, Paweł Wawrzyńczak, Zbigniew Buler, \\ Dorota Konopacka, Paweł Konopacki, Adam Krawiec, \\ Paweł Białkowski, Barbara Michalska, Marian Plaskota \\ and Bogdan Gotowicki
}

\author{
Research Institute of Horticulture, Pomology Department \\ Pomologiczna 18, 96-100 Skierniewice, POLAND
}

(Received February 17, 2012/Accepted June 18, 2012)

\section{A B S T R A C T}

Eleven plum cultivars (Prunus domestica L.) for processing grafted on semidwarf rootstock 'Wangenheim Prune' and vigorous rootstock 'Myrobalan' were densely planted $\left(1000,1250,1666,2500\right.$ trees ha $\left.{ }^{-1}\right)$ and trained to central leader spindle tree. A new training system was applied to obtain trees suitable for mechanical harvesting. The leader was not headed after planting and summer training procedures were performed in May/June. From the third year onwards, renewal pruning was carried out after fruit harvesting. The new training and pruning systems resulted in very fast tree growth, abundant branching, fruit bud formation on young wood and early bearing. The plum trees appeared to be suitable for hand and mechanical harvesting within 3 years from planting. The self propelled straddle combine harvester was able to harvest 2-3 tons of plums per hour compared to $30 \mathrm{~kg}$ with hand picking. Harvesting effectiveness was $90-95 \%$. The quality of mechanically harvested plums was a little worse than of those hand picked, but fruits were suitable for processing. The 'Common Prune' and the prune type small plums were the most suitable fruit for mechanical harvesting.

Key words: plums (Prunus domestica L.), training, pruning, canopy structure, fruiting biology

\section{INTRODUCTION}

In Western Europe, plums are grafted on 'Myrobalan B', 'St Julien A', 'Marianna' and other vegetatively propagated rootstocks (Nicotra and
Moser, 1995). In Poland, most of plum and prune trees are grafted on seedlings of selected types of Prunus divaricata Led. (Myrobalan seedling). Such trees are planted at $4 \times 3 \mathrm{~m}$ to $5 \mathrm{x}$ $5 \mathrm{~m}$ and trained to regulated leader 
tree. About $20 \%$ of trees are grafted on seedlings of 'Wangenheim Prune'. This cultivar is self-pollinated, so seed trees grown in isolation produce seedlings with a uniform growth habit (Sitarek et al., 2001). 'Wangenheim Prune' is compatible with all European plums and prunes. Cultivars grafted on 'Wangenheim Prune' are semi-dwarf, tolerant to arid soils common in Poland and very productive (Sitarek et al., 2001; Rozpara and Grzyb, 2007). Such trees should be suitable for dense planting in intensive orchards (Peppelman et al., 2007). In Germany, Zahn (1986, 1994) and Brunner (1990) introduced a central leader spindle and free spindle (without shoot bending) for dwarf and semidwarf densely planted plums and prunes. These systems, tested in Belgium (Wustenberghs and Keulemans, 1996) with 825 and 1250 trees per ha, appeared to be very economical in yielding and harvesting. In Poland, Mika and Buler (2011), diffused training trees to slender leader form by summer training procedures. To harvest plums, a harvester for morello cherry designed by the Research Institute of Pomology and Floriculture (Mika et al., 2011) was used.

\section{MATERIAL AND METHODS}

The goal of this work was to develop an intensive plum orchard suitable for both: hand and mechanical fruit harvesting. A straddle-type of morello cherry fruit harvester, a diesel-hydraulic driven combine with a wide range of velocity and shaking frequency adjustment, was used for mechanical fruits harvesting. Technical data of the harvester are as follows: length $8.4 \mathrm{~m}$ in working position, width $4.0 \mathrm{~m}$, height $3.9 \mathrm{~m}$, clearance $2.8 \mathrm{~m}$, power - $50 \mathrm{~kW}$ diesel engine, travel velocity 0.6$10 \mathrm{~km} \mathrm{~h}^{-1}$, number of shakers - 4, shaking frequency $0-20 \mathrm{~Hz}$, shaker fingers stroke $65-90 \mathrm{~mm}$, crew 3-5 people. For plum harvesting, the following improvements to the cherry harvester had been made:

1. The sealing/grabbing unit (which grabs the fruits falling from the tree) was redesigned.

2. The shape and fastening of the sealing scales were changed, which increased their range of deflection from $13 \mathrm{~cm}$ to $37 \mathrm{~cm}$. Also the beams of the four-bar linkage (to which the sealing scales are fastened) were redesigned to achieve a smooth surface on the tree side and get $7.5 \mathrm{~cm}$ of transverse travel capacity. These changes allowed to increase the tolerance in the harvester's position against the tree and caused complete elimination of tree trunk bruising by the machine's stationary elements.

3. The shape of the supports of the shakers' columns were changed to enlarge the gap between the shaker and the frame of the longitudinal conveyor and obtain a significant increase in the sealing scales deflection range.

4. The space between the lateral planes was increased by redesigning the longitudinal conveyors and cleaning unit: 
a) the longitudinal conveyors were redesigned to lower the level of the fruit chute (this enlarged the free space at the tree exit) and individual power systems for the conveyor motors were introduced so that they could be controlled independently of each other,

b) the rigid air ducts for collecting pollution were replaced by flexible pipes to increase horizontal clearance at the rear of the harvester.

5. The steering was moved down to the level of the front wheels to allow the operator careful driving along tree rows.

6. The length of the longitudinal conveyors was reduced and the short end conveyors completely removed to allow fruit collection directly into large bins and increase the harvester's maneuverability on headlands.

The harvesting of plums was carried out at a travel velocity of $0.8 \mathrm{~km} \cdot \mathrm{h}^{1}$ with shaking frequency $6 \mathrm{~Hz}$ for cultivars with large-size fruits and $8 \mathrm{~Hz}$ for cultivars with small-size. Shaker fingers stroke was $90 \mathrm{~mm}$.

To determine precisely the pruning methods for mechanical harvesting, the growth habit and canopy structure of 11 plum cultivars were also studied. Cultivars tolerant to the PPV virus were chosen, including the completely resistant cultivar 'Jojo' (Hartmann, 2007).

One-year-old feathered trees of 'Cacanska Rana', 'Cacanska Lepotica', 'Cacanska Najbolja', 'Diana', 'Katinka', and 'Silvia' grafted on a semi- dwarfing seedling rootstock 'Wangenheim Prune' were planted in the autumn of 2004 on an area of 0.5 ha, on a sandy-loam soil at the Research Institute of Pomology, Skierniewice. To determine the optimum tree spacing for collecting fruit with a combine harvester, three distances for inrow planting were used: $1.5 \mathrm{~m}, 2.0 \mathrm{~m}$, $2.5 \mathrm{~m}\left(1666,1250,1000\right.$ trees $\left.^{-1}\right)$ while maintaining the same distance of $4 \mathrm{~m}$ between the rows. Each cultivar was planted in two rows (each consisting of 36 trees): one for hand harvesting, the other for mechanical harvesting. In each row, the trees were arranged in three randomized blocks (a replication) with four trees per plot for each spacing.

Another experimental orchard was established in the spring of 2008 on an area of 2 ha mainly to test the manoeuvrability of the harvester and its efficiency. One-year-old trees of 'Cacanska Lepotica' and 'Jojo' grafted on 'Wangenheim Prune' were spaced at $4 \mathrm{~m}$ between rows and at 1.0 and $1.5 \mathrm{~m}$ in the row $\left(2500,1666\right.$ trees ha $\left.{ }^{-1}\right)$. The cultivars grafted on the 'Myrobalan' rootstock: 'Amers', 'Valjevka', 'Common Prune', and 'Elena', were spaced at $4 \mathrm{~m}$ between rows and at $1.5 \mathrm{~m}$ and $2.0 \mathrm{~m}$ in the row (1666, 1250 trees $\mathrm{ha}^{-1}$ ), and trained in the same way as the trees in the first experimental orchard. Each cultivar was planted in two rows (each consisting about 120 trees), for hand and mechanical harvesting, respectively. In each row, trees were arranged in two plots (two replications) with 25 or 35 trees per plot, depending on planting distance in the row. The two 
experimental plots were managed in the same way. A new way of tree training and pruning was used. All leaders not exceeding $1.7 \mathrm{~m}$ were not headed and lateral shoots were pruned lightly. Towards the end of May, for a period of three years, 2 or 3 of the top shoots competing with the leader were removed in order to stimulate leader branching. From the third year onwards, renewal pruning (introduced to Poland by Czynczyk et al., 1976) was implemented, which consisted in cutting out every year 3 or 4 of the oldest, large branches, while leaving a stump at the leader, and moderately thinning the canopy.

In the second year after planting, the inter-rows were grassed down, with frequent grass mowing in conjunction with the maintenance of 1.5-m-wide herbicide strips along the rows. A drip irrigation system was installed from the first year. This was necessary because annual precipitation at Skierniewice is around $500 \mathrm{~mm}$, whereas plums grown in central Poland require $700 \mathrm{~mm}$ of rainfall. Fertilizers were applied according to the standard recommendation for commercial plum orchards. Eight to ten sprayings were essential to control pests and diseases.

Every year, measurements of the diameter of the tree trunk were taken. The influence of the cultivars and planting distance on shoot growth, canopy structure, the relation between shoot age and fruit bud formation and fruit setting was recorded. At harvest, the following records were made: the force needed to detach fruit from stem, the quantities of the fruit collected, remaining on the tree and fallen to the ground, fruit yield per plot, harvesting efficiency in $\mathrm{kg} \mathrm{h}^{-1}$ and also the number of damaged shoots (broken or with the bark rubbed off). Fruit quality was evaluated in the laboratory after harvest and also after storage for 10 days at $18{ }^{\circ} \mathrm{C}$ and in cold storage at $5{ }^{\circ} \mathrm{C}$. Fruit firmness was evaluated with penetrometer Instron 4303, from a sample of 60 fruit from each treatment. Total soluble solids content (TSS) was measured in ground sample of the same amount of fruits. (Detailed results of that study will be a subject of a separate publication).

Two harvesting trials were performed. In year 2008 with 4-year-old trees: 'Cacanska Lepotica', 'Cacanska Najbolja', 'Cacanska Rana', 'Diana' 'Katinka', 'Silvia'. In year 2010 with 3year-old or 6-year-old trees: 'Amers', 'Cacanska Najbolja', 'Common Prune', 'Elena', 'Jojo, 'Silvia', 'Valjevka'. None harvesting trial was possible in 2009 due to flower spring frost damage.

The results were statistically elaborated using analysis of variance, followed by means separation using Duncan's multiple-range t-test at $\mathrm{p}<0.05$.

\section{RESULTS AND DISCUSSION}

In the first experimental orchard, established in 2004, the growth of trees in the sixth year from planting (2010), expressed by trunk crosssectional area (Tab. 1), showed significant differences between the cultivars and also significant differences between the densest tree spacing in the row. In the second experimental orchard (Tab. 2), trees grafted on the 
Mechanical harvesting of plums for processing....

Table 1. Trunk cross sectional area $\left[\mathrm{cm}^{2}\right]$ of six year old trees grafted on 'Wangenheim Prune' (2010)

\begin{tabular}{|l|c|}
\hline Influence of cultivars & Trunk cross-sectional area (TCSA) \\
\hline Cacanska Rana & $46.6 \mathrm{bc}^{*}$ \\
\hline Cacanska Najbolja & $52.9 \mathrm{~d}$ \\
\hline Cacanska Lepotica & $35.0 \mathrm{a}$ \\
\hline Diana & $42.8 \mathrm{~b}$ \\
\hline Katinka & $33.3 \mathrm{a}$ \\
\hline Silvia & $51.7 \mathrm{~cd}$ \\
\hline Influence of spacing [m] & \\
\hline $4 \times 1.5$ & $40.7 \mathrm{a}$ \\
\hline $4 \times 2.0$ & $45.6 \mathrm{~b}$ \\
\hline $4 \times 2.5$ & $44.8 \mathrm{~b}$ \\
\hline
\end{tabular}

*Different letters indicate significant difference, separately for cultivars and spacing, at $\mathrm{p}=0.05$

Table 2. Trunk cross sectional area $\left[\mathrm{cm}^{2}\right]$ of plum trees grafted on 'Myrobalan' (A) and 'Wangenheim Prune' (B) in the third year from planting (2010)

\begin{tabular}{|c|c|c|}
\hline \multicolumn{3}{|c|}{ A. Trees grafted on Myrobalan } \\
\hline & $4 \times 1.5 \mathrm{~m}$ & $4 \times 2 \mathrm{~m}$ \\
\hline Amers & $34.5 \mathrm{ab}^{*}$ & $38.7 \mathrm{c}$ \\
\hline Valjevka & $33.5 \mathrm{ab}$ & $34.4 \mathrm{ab}$ \\
\hline Common Prune & $31.8 \mathrm{a}$ & $33.9 \mathrm{ab}$ \\
\hline Elena & $36.9 \mathrm{bc}$ & $39.8 \mathrm{c}$ \\
\hline \multicolumn{3}{|c|}{ spacing on Myrobalan } \\
\hline $1.5 \mathrm{~m}$ & \multicolumn{2}{|c|}{$34.2 \mathrm{a}$} \\
\hline $2 \mathrm{~m}$ & \multicolumn{2}{|c|}{$36.7 \mathrm{~b}$} \\
\hline \multicolumn{3}{|c|}{ B. Trees grafted on Wangenheim Prune } \\
\hline & $4 \times 1 \mathrm{~m}$ & $4 \times 1.5 \mathrm{~m}$ \\
\hline Cacanska Lepotica & $16.3 \mathrm{ab}$ & $19.2 \mathrm{~b}$ \\
\hline Jojo & $15.9 \mathrm{a}$ & $17.3 \mathrm{ab}$ \\
\hline \multicolumn{3}{|c|}{ spacing on Wangenheim Prune } \\
\hline $1 \mathrm{~m}$ & \multicolumn{2}{|c|}{$16.1 \mathrm{a}$} \\
\hline $1.5 \mathrm{~m}$ & \multicolumn{2}{|c|}{$18.2 \mathrm{~b}$} \\
\hline \multicolumn{3}{|c|}{ Means for rootstocks } \\
\hline Myrobalan rootstock & & \\
\hline Wangenheim rootstock & \multicolumn{2}{|c|}{$17.2 \mathrm{a}$} \\
\hline
\end{tabular}

*Different letters indicate significant difference, separately for rootstocks, at $\mathrm{p}=0.05$ 
'Myrobalan' rootstock were twice as vigorous as those on 'Wangenheim Prune'. Such differences in tree vigour had been reported earlier by Rozpara and Grzyb (2007). Large differences also appeared in growth intensity between the cultivars and planting distances. The large difference in the growth intensity of the cultivars indicates that this factor should be considered in designing intensive plum orchards. The combination with the densest (smallest) spacing in the row resulted in a dwarfing effect on tree growth. When an orchard is managed for a long period, this dwarfing effect leads to lower crops from smaller trees. Such a result is often observed in intensive apple orchards (Mika and Piskor, 1996). The new implemented methods of tree training induced the leader to fast vertical growth and the formation of numerous lateral shoots. All the trees reached the required height (3.0$3.5 \mathrm{~m}$ ) in the fourth year after planting. In the successive years, tree height had to be restricted by pruning to match the trees with the required parameters of the harvester. For this reason, strong shoots appearing at the top of trees were removed from the $4^{\text {th }}$ year on both machine - and handharvested trees. Canopy spread tends to increase until the sixth year from planting, but it was restricted by renewal pruning consisting in replacing old branches with young shoots. This treatment assured uniform canopy spread. According to Peppelman et al. (2007), planting density in the range of 800 to 1400 trees $\mathrm{ha}^{-1}$ is only possible with trees on dwarfing rootstocks. Here, the authors hope, that with the renewal pruning system, the growth of trees grafted on the 'Myrobalan' rootstock will be kept to the required size for at least 15 years. The canopy structure, expressed by the percentage of shoots in 3 classes of length (Tab. 3), appeared to be favourable for the applied pruning system because most of new shoots were short, in the range from $5 \mathrm{~cm}$ to $50 \mathrm{~cm}$. Such shoots were able to form fruit buds on one-year-old wood.

Renewal pruning can be performed when trees set fruit buds on young wood. This phenomenon was studied over 3 years. Table 4 shows the ability of young wood to set fruit buds on fully-grown trees in the third year from planting. Most of the cultivars were able to set about $80 \%$ of fruit bud clusters on one-year-old and two-year-old wood, although many differences in this ability were found among the cultivars. The rest, nearly $20 \%$, was set on three-yearold wood. These results indicate that the trees subjected to renewal pruning produce enough fruiting wood and the pruning method should not have an adverse effect on tree yielding. Bare wood observed on trees subjected to traditional regulated pruning was not observed in this experiment. Detailed studies on flower bud formation revealed that fruit bud clusters on one-year-old wood consisted on average of fewer flowers than the clusters on older wood (Tab. 5). For this reason, one could expect that young wood may set less fruit than older wood. 
Mechanical harvesting of plums for processing....

Table 3. Structure of shoots as \% in three classes of length in four-year-trees (2008)

\begin{tabular}{|l|c|c|c|}
\hline $\begin{array}{c}\text { Influence } \\
\text { of cultivars }\end{array}$ & Class 5-50 cm & Class 51-90 cm & Class 91-150 cm \\
\hline Cacanska Rana & $74.3 \mathrm{ij}^{*}$ & $18.9 \mathrm{cde}$ & $6.8 \mathrm{ab}$ \\
\hline Cacanska Najbolja & $63.1 \mathrm{hi}$ & $31.9 \mathrm{ef}$ & $5.0 \mathrm{a}$ \\
\hline Cacanska Lepotica & $61.4 \mathrm{gh}$ & $13.9 \mathrm{bcd}$ & $24.7 \mathrm{def}$ \\
\hline Diana & $50.3 \mathrm{~g}$ & $35.2 \mathrm{f}$ & $14.5 \mathrm{bcd}$ \\
\hline Katinka & $75.2 \mathrm{j}$ & $14.6 \mathrm{bcd}$ & $10.2 \mathrm{abc}$ \\
\hline Silvia & $55.1 \mathrm{gh}$ & $23.0 \mathrm{def}$ & $21.9 \mathrm{def}$ \\
\hline Influence of spacing $(\mathrm{m})$ & $62.1 \mathrm{c}$ & $22.2 \mathrm{~b}$ & $15.7 \mathrm{ab}$ \\
\hline $4 \times 1.5$ & $63.1 \mathrm{c}$ & $23.5 \mathrm{~b}$ & $13.4 \mathrm{a}$ \\
\hline $4 \times 2.0$ & $65.1 \mathrm{c}$ & $23.1 \mathrm{~b}$ & $11.8 \mathrm{a}$ \\
\hline $4 \times 2.5$ &
\end{tabular}

*Different letters indicate significant difference, separately for cultivars and spacing, at $\mathrm{p}=0.05$

Table 4. Percentage of fruit bud clusters on young wood in the third year from planting (2010)

\begin{tabular}{|l|c|c|c|}
\hline \multirow{2}{*}{\begin{tabular}{c}
\multirow{2}{*}{$\begin{array}{c}\text { Influence } \\
\text { of cultivars }\end{array}$} \\
\cline { 2 - 4 }
\end{tabular}} & \multicolumn{3}{|c|}{ Shoot age } \\
\hline Cacanska Lepotica & $38.4 \mathrm{ab}^{*}$ & 2-year-old & 3-year-old \\
\hline Amers & $39.0 \mathrm{ab}$ & $35.5 \mathrm{a}$ & $26.1 \mathrm{~b}$ \\
\hline Jojo & $55.3 \mathrm{~b}$ & $39.0 \mathrm{a}$ & $22.0 \mathrm{ab}$ \\
\hline Valjevka & $51.3 \mathrm{ab}$ & $36.0 \mathrm{a}$ & $8.7 \mathrm{a}$ \\
\hline Common Prune & $44.7 \mathrm{ab}$ & $33.6 \mathrm{a}$ & $15.1 \mathrm{ab}$ \\
\hline Elena & $35.8 \mathrm{a}$ & $42.4 \mathrm{a}$ & $12.9 \mathrm{ab}$ \\
\hline
\end{tabular}

*Different letters indicate significant difference at $\mathrm{p}=0.05$

Table 5. The number of flowers in one fruit bud cluster in the third year from planting (2010)

\begin{tabular}{|c|c|c|c|}
\hline \multirow{2}{*}{$\begin{array}{l}\text { Influence } \\
\text { of cultivars }\end{array}$} & \multicolumn{3}{|c|}{ Shoot age } \\
\hline & 1-year-old & 2-year-old & 3-year-old \\
\hline Cacanska Lepotica & $2.4 \mathrm{c}^{*}$ & $2.3 \mathrm{ab}$ & $1.8 \mathrm{a}$ \\
\hline Amers & $2.5 \mathrm{c}$ & $3.2 \mathrm{c}$ & $3.5 \mathrm{c}$ \\
\hline Jojo & $2.3 \mathrm{bc}$ & $2.7 \mathrm{bc}$ & $4.9 \mathrm{~d}$ \\
\hline Valjevka & $1.6 \mathrm{a}$ & $2.4 \mathrm{ab}$ & $1.9 \mathrm{a}$ \\
\hline Common Prune & $1.6 \mathrm{a}$ & $1.9 \mathrm{a}$ & $2.7 \mathrm{~b}$ \\
\hline Elena & $1.9 \mathrm{ab}$ & $1.9 \mathrm{a}$ & $1.8 \mathrm{a}$ \\
\hline Mean & $2.05 \mathrm{a}$ & $2.40 \mathrm{~b}$ & $2.76 \mathrm{c}$ \\
\hline
\end{tabular}

*Different letters indicate significant difference at $\mathrm{p}=0.05$ 
However, this was not proved. Most of the cultivars set more fruit on one-yearold and two-year-old wood than on three-year-old wood (Tab. 6). As a result of that, the percentage of fruit on one-year-old and two-year-old wood was similar to the percentage of flower bud clusters, that is, around $80 \%$ (Tab. 7).

The trees in the first experimental orchard began to bloom in the second year after planting and produced about 0.3 to $1.0 \mathrm{~kg}$ of fruit per tree. In the third year (2007), flowers were killed by a spring frost in May. For this reason, the first yield was obtained in the fourth year after planting. Most of the trees produced from 10 to $15 \mathrm{~kg}$ of fruit per tree (Tab. 8). The most productive was 'Cacanska Najbolja', the least - 'Cacanska Rana'. There were many differ- ences between the cultivars, but few between the planting distances. Only 'Cacanska Najbolja' and 'Diana' gave higher crops when planted at a larger distance. In the fifth year, a spring frost in May again reduced crops to below one kg per tree. Acceptable yields were produced in the sixth year after planting (2010). Most of the trees yielded 11$17 \mathrm{~kg}$ per tree. The size of yield was comparable to that obtained earlier in a variety trial with the same two cultivars by Rozpara and Grzyb (2007). There were again very large differences in tree productivity between the cultivars, but none between the planting distances. This suggests that when renewal pruning is performed, trees can be spaced even at $1.5 \mathrm{~m}$ in the row. In terms of per hectare, the yield of most cultivars was from 14 to 21 tons.

Table 6. Fruit set in three-year-old trees expressed as the percentage of fruit to bud clusters (2010)

\begin{tabular}{|l|c|c|c|}
\hline \multirow{2}{*}{ Influence of cultivars } & \multicolumn{3}{|c|}{ Shoot age } \\
\cline { 2 - 4 } & 1-year-old & 2-year-old & 3-year-old \\
\hline Cacanska Lepotica & $15.0 \mathrm{a}^{*}$ & $21.3 \mathrm{a}$ & $31.4 \mathrm{~b}$ \\
\hline Amers & $8.5 \mathrm{a}$ & $27.2 \mathrm{a}$ & $9.4 \mathrm{a}$ \\
\hline Jojo & $34.5 \mathrm{~b}$ & $28.9 \mathrm{a}$ & $6.9 \mathrm{a}$ \\
\hline Valjevka & $16.0 \mathrm{a}$ & $19.3 \mathrm{a}$ & $5.8 \mathrm{a}$ \\
\hline Common Prune & $11.3 \mathrm{a}$ & $25.9 \mathrm{a}$ & $6.5 \mathrm{a}$ \\
\hline Elena & $55.0 \mathrm{c}$ & $31.0 \mathrm{a}$ & $32.4 \mathrm{~b}$ \\
\hline Mean & $23.4 \mathrm{~b}$ & $25.6 \mathrm{~b}$ & $15.4 \mathrm{a}$ \\
\hline
\end{tabular}

*Different letters indicate significant difference at $\mathrm{p}=0.05$

Table 7. Percentage of fruit on young wood in the third year from planting (2010)

\begin{tabular}{|l|c|c|c|}
\hline \multirow{2}{*}{ Influence of cultivars } & \multicolumn{3}{|c|}{ Shoot age } \\
\cline { 2 - 4 } & 1-year-old & 2-year-old & 3-year-old \\
\hline 'Cacanska Lepotica' & $35.2 \mathrm{ab} *$ & $35.9 \mathrm{ab}$ & $28.9 \mathrm{~b}$ \\
\hline 'Amers' & $18.0 \mathrm{a}$ & $69.1 \mathrm{c}$ & $12.9 \mathrm{ab}$ \\
\hline 'Jojo' & $50.4 \mathrm{ab}$ & $35.1 \mathrm{ab}$ & $14.5 \mathrm{ab}$ \\
\hline 'Valjevka' & $50.1 \mathrm{ab}$ & $43.6 \mathrm{abc}$ & $6.3 \mathrm{a}$ \\
\hline 'Common Prune' & $26.9 \mathrm{ab}$ & $67.9 \mathrm{bc}$ & $5.2 \mathrm{a}$ \\
\hline 'Elena' & $56.1 \mathrm{~b}$ & $28.8 \mathrm{a}$ & $15.1 \mathrm{ab}$ \\
\hline Mean & $39.5 \mathrm{~b}$ & $46.7 \mathrm{~b}$ & $13.8 \mathrm{a}$ \\
\hline
\end{tabular}

*Different letters indicate significant difference at $\mathrm{p}=0.05$ 
Table 8 . Yield $(\mathrm{kg} / \mathrm{tree})$ and index productivity $\left[\mathrm{kg} / \mathrm{cm}^{2}\right]$ in the fourth and sixth years from planting $\left(2008\right.$ and $\left.2010^{1}\right)$

\begin{tabular}{|l|c|c|c|c|}
\hline $\begin{array}{c}\text { Influence } \\
\text { of cultivars }\end{array}$ & 2008 & 2010 & Total & $\begin{array}{c}\text { Index } \\
\text { productivity }\end{array}$ \\
\hline Cacanska Rana & $9.7 \mathrm{a}^{*}$ & $16.5 \mathrm{~b}$ & $26.2 \mathrm{a}$ & $0.56 \mathrm{a}$ \\
\hline Cacanska Najbolja & $28.6 \mathrm{c}$ & $29.0 \mathrm{c}$ & $57.6 \mathrm{~b}$ & $1.09 \mathrm{~b}$ \\
\hline Cacanska Lepotica & $11.4 \mathrm{ab}$ & $16.1 \mathrm{~b}$ & $27.5 \mathrm{a}$ & $0.79 \mathrm{a}$ \\
\hline Diana & $14.5 \mathrm{~b}$ & $17.1 \mathrm{~b}$ & $31.6 \mathrm{a}$ & $0.74 \mathrm{a}$ \\
\hline Katinka & $15.0 \mathrm{~b}$ & $11.7 \mathrm{a}$ & $26.7 \mathrm{a}$ & $0.80 \mathrm{a}$ \\
\hline \multicolumn{5}{|l|}{} \\
\hline Influia & $14.6 \mathrm{~b}$ & $11.1 \mathrm{a}$ & $25.7 \mathrm{a}$ & $0.50 \mathrm{a}$ \\
\hline $4 \times 1.5$ & $13.8 \mathrm{a}$ & $12.7 \mathrm{a}$ & $26.5 \mathrm{a}$ & $0.65 \mathrm{a}$ \\
\hline $4 \times 2.0$ & $14.3 \mathrm{~b}$ & $12.2 \mathrm{a}$ & $26.5 \mathrm{a}$ & $0.58 \mathrm{a}$ \\
\hline $4 \times 2.5$ & $16.0 \mathrm{c}$ & $13.9 \mathrm{a}$ & $29.9 \mathrm{a}$ & $0.67 \mathrm{a}$ \\
\hline
\end{tabular}

${ }^{1}$ Yields in 2007 and 2009 were affected by spring frosts

*Different letters indicate significant difference, separately for cultivars and spacing, at $\mathrm{p}=0.05$

In the second experimental orchard, planted in 2008, trees grew much faster than in the first one and started to produce fruit in the second year from planting (1-3 kg per tree). In the third year, they delivered a sufficient crop to be harvested by the combine harvester (Tab. 9).

Plums were harvested with the combine harvester and picked by hand in two successive years (2008 and 2010) in the first experimental orchard and in one year (2010) in the second experimental orchard. Cultivars were mechanically harvested and compared with hand picking. Tables 10 and 12 present the results of mechanical harvesting in the years 2008 and 2010 when fruit yields were the highest.

In Table 10, there are results of harvesting in 2008 four-year-old semidwarf trees grafted on 'Wangenheim Prune'. Because of small, weak and flexible branches, harvesting was very efficient with only negligible damage to trees. Harvesting was started when the force of detachment between fruit and stem was 6-8 $\mathrm{N}$, fruit firmness $4-5 \mathrm{~N}$, TSS $13-15 \%$. The proper time of harvesting plums plays an important role in their shelf-life (Bengtsson et al., 2007). The effectiveness of mechanical harvesting of five cultivars was about $95 \%$ with about $5 \%$ of the fruit left on the tree or lost on the ground, with the exception of 'Cacanska Najbolja', for which harvesting effectiveness was only $83 \%$. Labour efficiency was calculated as $2-3 \mathrm{th}^{-1}$ depending on the size of the crop. The plums harvested by machine and picked by hand varied only a little in quality (Tab. 11). Up to about $10 \%$ of plums sustained visual damage after mechanical harvesting. The plums were all fully acceptable for processing. After grading and rejection of the damaged ones, the remainder looked like the plums picked by hand. However, when kept at room temperature for a few days, they developed bruising in the form of brown spots. 
A. Mika et al.

Table 9. Total yield in kg/tree trees grafted on 'Myrobalan' (A) and 'Wangenheim

Prune' (B) planted in different distance (2010)

\begin{tabular}{|c|c|c|}
\hline \multicolumn{3}{|c|}{ A. Trees grafted on Myrobalan } \\
\hline & $4 \times 1.5 \mathrm{~m}$ & $4 \times 2 \mathrm{~m}$ \\
\hline Amers & $6.9 \mathrm{c}^{*}$ & $8.8 \mathrm{~d}$ \\
\hline Valjevka & $4.6 \mathrm{~b}$ & $4.6 \mathrm{~b}$ \\
\hline Common Prune & $2.4 \mathrm{a}$ & $3.0 \mathrm{a}$ \\
\hline Elena & $8.7 \mathrm{~d}$ & $8.8 \mathrm{~d}$ \\
\hline \multicolumn{3}{|c|}{ spacing on Myrobalan } \\
\hline $1.5 \mathrm{~m}$ & \multicolumn{2}{|c|}{$5.4 \mathrm{a}$} \\
\hline $2 \mathrm{~m}$ & \multicolumn{2}{|c|}{$6.0 \mathrm{~b}$} \\
\hline \multicolumn{3}{|c|}{ B. Trees grafted on Wangenheim Prune } \\
\hline & $4 \times 1 \mathrm{~m}$ & $4 \times 1.5 \mathrm{~m}$ \\
\hline Cacanska Lepotica & $4.9 \mathrm{a}$ & $6.7 \mathrm{a}$ \\
\hline Jojo & $10.3 \mathrm{~b}$ & $12.0 \mathrm{~b}$ \\
\hline \multicolumn{3}{|c|}{ spacing on Wangenheim Prune } \\
\hline $1 \mathrm{~m}$ & \multicolumn{2}{|c|}{$7.4 \mathrm{a}$} \\
\hline $1.5 \mathrm{~m}$ & \multicolumn{2}{|c|}{$9.2 \mathrm{a}$} \\
\hline
\end{tabular}

*Different letters indicate significant difference, separately for rootstocks, at $\mathrm{p}=0.05$

Table 10. Effectiveness of mechanical harvesting of four-year-old plum trees (2008) expressed in $\mathrm{kg}$ and \%

\begin{tabular}{|l|c|c|c|c|c|c|}
\hline $\begin{array}{c}\text { Cultivar and date of } \\
\text { harvesting }\end{array}$ & $\begin{array}{c}\text { Fruits } \\
\text { collected } \\
{[\mathrm{kg} / \%]}\end{array}$ & $\begin{array}{c}\text { Fruits } \\
\text { remaining } \\
\text { on the tree } \\
{[\mathrm{kg} / \%]}\end{array}$ & $\begin{array}{c}\text { Fruits lost } \\
\text { on the } \\
\text { ground } \\
{[\mathrm{kg} / \%]}\end{array}$ & $\begin{array}{c}\text { Total } \\
\text { yield } \\
{[\mathrm{kg} / \%]}\end{array}$ & $\begin{array}{c}\text { Number } \\
\text { of trees } \\
\text { harvested }\end{array}$ & $\begin{array}{c}\text { Mean } \\
\text { yield } \\
{[\mathrm{kg} / \text { tree }]}\end{array}$ \\
\hline Cacanska Rana - & $296 /$ & $4.4 /$ & $9.5 /$ & $310 /$ & 35 & 8.9 \\
28.07 & 95.5 & 1.4 & 3.1 & 100 & & \\
\hline Diana - 23.07 & $473 /$ & $4.5 /$ & $12.0 /$ & $490 /$ & 35 & 14.0 \\
\hline Katinka-28.07 & 96.7 & 0.9 & 2.4 & 100 & & \\
\hline Silvia-6.08 & $339 /$ & $13.4 /$ & $11.5 /$ & $364 /$ & 30 & 12.1 \\
\hline Cacanska Lepotica - & 93.1 & 3.7 & 3.2 & 100 & & \\
12.08 & $688 /$ & $11.6 /$ & $11.6 /$ & $712 /$ & 36 & 19.8 \\
\hline Cacanska Najbolja - & 96.8 & 1.6 & 1.6 & 100 & & \\
25.08 & 95.3 & $7.0 /$ & $11.0 /$ & $385 /$ & 35 & 11.0 \\
\hline
\end{tabular}


Mechanical harvesting of plums for processing....

Table 11. Fruit quality harvested with a combine harvester (C) compared to the quality of hand-picked (H) (2008)

\begin{tabular}{|c|c|c|c|c|c|c|c|}
\hline \multicolumn{2}{|c|}{ Cultivar } & $\begin{array}{c}\text { Mean } \\
\text { fruit } \\
\text { weight } \\
{[\mathrm{g}]} \\
\end{array}$ & $\begin{array}{c}\text { Firmness } \\
{[\mathrm{N}]}\end{array}$ & $\begin{array}{c}\text { Total } \\
\text { Soluble } \\
\text { Solids } \\
{[\%]}\end{array}$ & $\begin{array}{c}\text { Damaged } \\
\text { fruit } \\
{[\%]}\end{array}$ & $\begin{array}{c}\text { Rotten } \\
\text { fruit } \\
{[\%]}\end{array}$ & $\begin{array}{c}\text { Unripened } \\
\text { fruit } \\
{[\%)}\end{array}$ \\
\hline Cacanska & $\mathrm{C}$ & 37.0 & 5.4 & 14.6 & 4.5 & 11.0 & 16.6 \\
\hline Rana & $\mathrm{H}$ & 37.0 & 5.4 & 14.6 & 1.3 & 13.2 & 14.0 \\
\hline \multirow{2}{*}{ Diana } & $\mathrm{C}$ & 34.9 & 5.2 & 12.4 & 7.9 & - & 12.7 \\
\hline & $\mathrm{H}$ & 34.9 & 5.2 & 12.4 & 1.3 & - & 5.2 \\
\hline \multirow{2}{*}{ Katinka } & $\mathrm{C}$ & 13.2 & 4.0 & 13.8 & 5.4 & - & 5.7 \\
\hline & $\mathrm{H}$ & 13.2 & 4.0 & 13.8 & 3.7 & 1.4 & 11.6 \\
\hline \multirow{2}{*}{ Silvia } & $\mathrm{C}$ & 38.1 & 4.6 & 15.6 & 9.6 & 6.6 & 3.1 \\
\hline & $\mathrm{H}$ & 38.1 & 4.6 & 15.6 & - & 10.5 & 4.2 \\
\hline Cacanska & $\mathrm{C}$ & 38.2 & 4.5 & 13.7 & 2.5 & 1.5 & 2.0 \\
\hline Lepotica & $\mathrm{H}$ & 38.2 & 4.5 & 13.7 & - & 5.0 & 3.0 \\
\hline Cacanska & $\mathrm{C}$ & 32.5 & 10.3 & 13.8 & 1.8 & - & - \\
\hline Najbolja & $\mathrm{H}$ & 32.5 & 10.3 & 13.8 & - & 0.9 & - \\
\hline
\end{tabular}

Table 12. Effectiveness of mechanical harvesting of fruits from three-year-old and six-year-old trees grafted on 'Wangenheim Prune' and 'Myrobalan' (2010)

\begin{tabular}{|c|c|c|c|c|c|c|}
\hline $\begin{array}{l}\text { Cultivar and time } \\
\text { of harvesting }\end{array}$ & $\begin{array}{c}\text { Fruits } \\
\text { collected } \\
{[\mathrm{kg} / \%]}\end{array}$ & $\begin{array}{l}\text { Fruits remain- } \\
\text { ing on the tree } \\
{[\mathrm{kg} / \%]}\end{array}$ & $\begin{array}{l}\text { Fruits lost } \\
\text { on the } \\
\text { ground } \\
{[\mathrm{kg} / \%]}\end{array}$ & $\begin{array}{l}\text { Total } \\
\text { yield } \\
{[\mathrm{kg} / \%]}\end{array}$ & $\begin{array}{c}\text { Number } \\
\text { of trees }\end{array}$ & $\begin{array}{c}\text { Yield } \\
{[\mathrm{kg} / \text { tree }]}\end{array}$ \\
\hline Amers & 360 & 7.3 & 26.0 & 393 & 60 & 6.6 \\
\hline 07.09 & 91.5 & 1.9 & 6.6 & 100 & & \\
\hline Jojo* & 733 & 23.9 & 95.8 & 852 & 84 & 10.2 \\
\hline 09.09 & 86.0 & 2.8 & 11.2 & 100 & & \\
\hline Valjevka & 145 & 1,3 & 26.5 & 173 & 60 & 2.9 \\
\hline 09.09 & 83.9 & 0.8 & 15.4 & 100 & & \\
\hline C. Najbolja & 782 & 27.5 & 88.0 & 897 & 39 & 23.0 \\
\hline 26.08 & 87.1 & 3.1 & 9.8 & 100 & & \\
\hline Silvia & 332 & 5.0 & 16.7 & 354 & 38 & 9.3 \\
\hline 16.08 & 93.9 & 1.4 & 4.7 & 100 & & \\
\hline C. Lepotica* & 308 & 5.8 & 25.2 & 339 & 35 & 9.7 \\
\hline 16.08 & 90.9 & 1.7 & 7.4 & 100 & & \\
\hline Common Prune & 127 & 6.1 & 27.7 & 160 & 60 & 2.7 \\
\hline 07.10 & 78.9 & 3.8 & 17.3 & 100 & & \\
\hline Elena & 461 & 9.3 & 33.0 & 503 & 60 & 8.4 \\
\hline 07.10 & 91.6 & 1.9 & 6.6 & 100 & & \\
\hline
\end{tabular}

*Trees grafted on 'Wangenheim Prune' rootstocks 
Harvesting effectiveness in the first and second experimental orchard, in 2010 (Tab. 12), was lower because of many strongly growing shoots and branches in the canopy structure. Some branches received vibrations prior to fully coming within the reach of the machine and in those cases some of the plums dropped to the ground. Because of stiffness, some branches (2-3 per tree) got broken or had the bark peeled off. No damage to the trunk or the leader was observed.

\section{CONCLUSIONS}

1. The new training system of plum trees without leader heading after tree planting and the implementation of summer training procedures resulted in rapid tree growth, abundant lateral branching of the leader and early fruit bearing.

2. Plum trees trained to the leader and pruned by the renewal method are able to form a majority of fruit buds on young wood and also an abundant fruit set.

3. Plum trees spaced at $4 \mathrm{~m}$ between the rows and $1.5-2.0 \mathrm{~m}$ in the row, trained to the leader and subjected to renewal pruning, are suitable for hand and mechanical harvesting with a self-propelled straddle harvester working in continuous motion.

4. The effectiveness of harvesting with the combine harvester of seven cultivars over two years varied between 90-95\%. Between $4 \%$ and $10 \%$ of plums were left on the tree or lost on the ground. Four cultivars were harvested with an effectiveness below $90 \%$.

5. Up to about $10 \%$ of the plums harvested mechanically showed visible damage after harvesting. They were fully acceptable for processing, but not as dessert plums because they developed brown spots on the shop shelf.

\section{REFERENCES}

Bengtsson G.B., Lundby F., Haugen J.E. 2007. Rapid analytical techniques for measurement of plum ripeness postharvest. ACTA HORT. 734: 211-216.

Brunner T. 1990. Pruning with bending effect on the basis of inducing hypotonic ramification. Physiological fruit tree training for intensive culture. Akademiai Kiado, Budapest: 81-97.

Czynczyk A., Mika A., Chlebowska D. 1976. Progress report on 12 years of experimentation with established spur, renewal and regulated pruning of apple trees. FRUIT SCI. REP. 3(2): 25-28.

Hartmann W. 2007. New Results from plant breeding in Hoheheim. ACTA HORT. 734: 187-192.

Mika A., Buler Z. 2011. Intensive plum orchard with summer training and pruning - ADV. HORT. SCI. 25(3): 1-6.

Mika A., Piskor E. 1996. Growth and cropping of dwarf 'Jonagold' ('Jonica') apple trees planted at the density ranged from 2000 to 10000 per ha and trained as slender spindle, super spindle and V system. ACTA HORT. 451: 473-477.

Mika A., Buler Z., Michalska B. 2011. Biology of flowering and fruiting of sour cherry trees grown at high density. FRUIT SCI. REP. 19(1): 123-136. 
Nicotra A., Moser L. 1995. Orientamenti per la scelta dei portinnesti del susino. INFORMATORE AGRARIO 32: 43-45.

Peppelman G., Kemp H., Balkhoven-Baart J.M.T., Groot M.J. 2007. Towards high density plum growing - agronomic and economic performance of plum (Prunus domestica L.) on 'VVA-1' rootstock. ACTA HORT. 734: 225-230.

Rozpara E., Grzyb Z.S. 2007. Growth, yield and fruit quality of eighteen plum cultivars grafted on two rootstocks. ACTA HORT. 734: 157-161.

Sitarek M., Grzyb Z.S., Kołodziejczak P. 2001. Effect of rootstocks on growth and yield of plum trees. J. FRUIT ORNAM. PLANT RES. IX(1-4): 19-24.

Wustenberghs H., Keulemans J. 1996. A comparison of 3 plum tree training systems during the first five years of growth. ACTA HORT. 451: 625-631.

Zahn F.G. 1986. Intensivierung von Steinobstanlagen durch stärkenbezogene Schnittbehandlung. Erwerbsobstbau 28: 124-140.

Zahn F.G. 1994. Hohengerechter Pflanzabstand durch Stärkenbezogene Baumbehandlung. Erwerbsobstbau 36: 213-220.

\title{
ZBIÓR KOMBAJNEM W RUCHU CIĄGŁYM ŚLIWEK PRZEZNACZONYCH DO PRZETWÓRSTWA
}

\author{
Augustyn Mika, Paweł Wawrzyńczak, Zbigniew Buler, \\ Dorota Konopacka, Paweł Konopacki, Adam Krawiec, \\ Paweł Białkowski, Barbara Michalska, Marian Plaskota \\ i Bogdan Gotowicki
}

\author{
S T R E S Z C Z E N I E
}

W Sadzie Doświadczalnym w Dąbrowicach posadzono jedenaście odmian śliw na półkarłowej podkładce 'Węgierka Wangenheima' i na silnie rosnącej podkładce 'Ałycza' w różnej gęstości (1000, 1250, 1666, 2500 drzew na ha). Drzewa były prowadzone w formie korony wrzecionowej z centralnym przewodnikiem. Nowy system formowania drzew zastosowano w celu mechanicznego zbioru owoców kombajnem. Przewodniki drzew nie przycinano po posadzeniu, a letnie formowanie wykonywano na przełomie maja i czerwca. Od trzeciego roku po posadzeniu drzew wykonywano cięcie odnawiające. Nowy system formowania i cięcia spowodował bardzo szybki wzrost drzew, obfite rozgałęzianie się pędów, formowanie się pąków kwiatowych i zawiązków owocowych na młodych pędach oraz wczesne owocowanie. Śliwy po trzech latach od posadzenia nadawały się do ręcznego i mechanicznego zbioru owoców. Kombajn samojezdny zbierał od 2 do 3 ton śliwek na godzinę w porównaniu z 30 kg owoców na godzinę przy zbiorze ręcznym. Wydajność zbioru kombajnem dla 
A. Mika et al.

większości odmian wynosiła od 90\% do 95\%. Jakość śliwek zebranych mechanicznie była trochę gorsza niż zbieranych ręcznie, ale owoce nadawały się do przetwórstwa. Owoce odmian drobnoowocowych były odpowiedniejsze do mechanicznego zbioru kombajnem.

Słowa kluczowe: śliwa, formowanie, cięcie, struktura korony, biologia owocowania 